\title{
Secondary Alcohol Hemiacetal Formation: an in situ Carbonyl Activation Strategy
}

\author{
Lei You and Eric V. Anslyn*
}

Supporting Information

\section{Experimental Section}

General. ${ }^{1} \mathrm{H}-\mathrm{NMR},{ }^{13} \mathrm{C}-\mathrm{NMR}$ and ${ }^{19} \mathrm{~F}-\mathrm{NMR}$ were recorded at a $300 \mathrm{MHz}$ or 400 $\mathrm{MHz}$ Varian Mercury spectrometer. UV titration and kinetics were performed on a Beckman DU-640 UV-Vis spectrophotometer. The glassware for the synthesis was flame-dried and the compound $\mathbf{1}$ was stored under argon. Compounds 2-4 were commercially available. All the anhydrous solvents for the titration were stored with $3 \AA$ molecular sieves. All measurements were performed at $25^{\circ} \mathrm{C}$.

Synthesis of 2-difluoroacetylpyridine (1). To anhydrous $\mathrm{Et}_{2} \mathrm{O}(10 \mathrm{~mL})$ under argon cooled at $-45^{\circ} \mathrm{C}$ (dry ice-ethanol slurry), was added $n$-BuLi $(1 \mathrm{M}$ in hexanes,

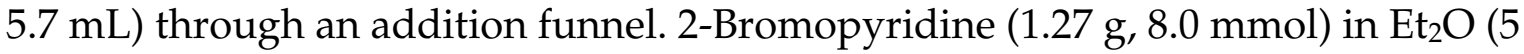
$\mathrm{mL}$ ) was then added to the mixture. The dark orange-red solution was stirred for 20 min and cooled to $-70{ }^{\circ} \mathrm{C}$ by adding $\mathrm{Et}_{2} \mathrm{O}$ and dry ice to the cooling bath. To 2pyridyllithium in $\mathrm{Et}_{2} \mathrm{O}$ cooled at $-70{ }^{\circ} \mathrm{C}$, was added ethyl difluoroacetate $(1.29 \mathrm{~g}$, $10.4 \mathrm{mmol})$ in $\mathrm{Et}_{2} \mathrm{O}(10 \mathrm{~mL})$ dropwise. The mixture was continued to stir at $-70{ }^{\circ} \mathrm{C}$ for $2 \mathrm{~h}$. After warming to room temperature, the yellow solution was poured into water: $2 \mathrm{M}$ sulfuric acid mixture $(1: 1,80 \mathrm{~mL})$ and transferred into a separatory funnel. The ether layer was extracted with $2 \mathrm{M}$ sulfuric acid $(2 \times 30 \mathrm{~mL})$. The aqueous layers were combined and adjusted to $\mathrm{pH} 10 \sim 11$ by $\mathrm{NaOH}$. The brown mixture formed was extracted with $\mathrm{Et}_{2} \mathrm{O}(4 \times 40 \mathrm{~mL})$. The organic layers were combined, dried $\left(\mathrm{Na}_{2} \mathrm{SO}_{4}\right)$, and concentrated. The crude product was purified by column chromatography (silica gel, hexane: EtOAc $=9: 1$ to 4:1) to afford a yellow oil $(0.56 \mathrm{~g}, 44 \%)$. Both ketone and hydrate were observed in NMR. The mixture was dehydrated after stirring in $\mathrm{CH}_{3} \mathrm{CN}$ in the presence of $3 \AA$ molecular sieves. ${ }^{1} \mathrm{H}-\mathrm{NMR}\left(400 \mathrm{MHz}, \mathrm{CD}_{3} \mathrm{CN}\right)$ : $\delta 7.19(1 \mathrm{H}, \mathrm{t}, J=54 \mathrm{~Hz}), \delta 7.69(1 \mathrm{H}, \mathrm{ddd}, J=7.6,4.6$, $1.4 \mathrm{~Hz}), \delta 8.03(1 \mathrm{H}, \mathrm{td}, J=7.6,1.6 \mathrm{~Hz}), \delta 8.12(1 \mathrm{H}, \mathrm{dt}, J=7.6,1.2 \mathrm{~Hz}), \delta 8.74-8.80$ $(1 \mathrm{H}, \mathrm{m}) .{ }^{19} \mathrm{~F}-\mathrm{NMR}\left(400 \mathrm{MHz}, \mathrm{CD}_{3} \mathrm{CN}\right): \delta-131.4(2 \mathrm{~F}, \mathrm{~d}, J=54 \mathrm{~Hz}) .{ }^{13} \mathrm{C}-\mathrm{NMR}(300$ $\left.\mathrm{MHz}, \mathrm{CDCl}_{3}\right): \delta 107.6(\mathrm{t}), 123.9(\mathrm{~s}), 128.7(\mathrm{~s}), 137.6(\mathrm{~s}), 149.7(\mathrm{~s}), 150.6(\mathrm{~s}), 187.4(\mathrm{t})$. 98\% purity by LC/MS: m/z $158.29\left([\mathrm{M}+\mathrm{H}]^{+}\right), 176.13\left(\left[\mathrm{M}+\mathrm{H}_{2} \mathrm{O}+\mathrm{H}\right]^{+}\right)$.

NMR Titrations and Reactions Screen. For NMR titrations, a mixture of host 1 
(30- $40 \mathrm{mM}$ ), 2-propanol (5 equiv) and methanesulfonic acid (0- 2 equiv) in $\mathrm{CD}_{3} \mathrm{CN}$ $(0.85 \mathrm{~mL})$ in the presence of $3 \AA$ molecular sieves, was stirred at room temperature for $2 \mathrm{~h}$. The ${ }^{1} \mathrm{H}-\mathrm{NMR}$ and ${ }^{19} \mathrm{NMR}$ spectra were recorded after $4 \mathrm{~h}, 24 \mathrm{~h}$ and $48 \mathrm{~h}$. For the control experiments, a mixture of host 1 or 4, 2-propanol (5 eq.) and $\mathrm{In}(\mathrm{OTf})_{3}\left(0-1\right.$ eq.) in $\mathrm{CD}_{3} \mathrm{CN}(0.85 \mathrm{~mL})$ in the presence of $3 \AA$ molecular sieves was stirred at room temperature for $2 \mathrm{~h}$. The ${ }^{1} \mathrm{H}-\mathrm{NMR}$ and ${ }^{19} \mathrm{NMR}$ spectra were recorded after $4 \mathrm{~h}, 24 \mathrm{~h}$ and $48 \mathrm{~h}$. For screening of hosts and acids, the host, alcohol, and acid were stirred in $\mathrm{CD}_{3} \mathrm{CN}$ for $2 \mathrm{~h}$, and the NMR spectra were taken afterwards. The percentage of each component in the reaction mixture was calculated from the integrations of ${ }^{1} \mathrm{H}-\mathrm{NMR}$ and ${ }^{19} \mathrm{~F}-\mathrm{NMR}$ spectra.

UV Titrations and Kinetics Measurements. The stock solutions of host 1, 2-

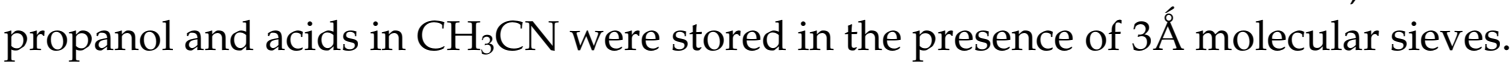
For UV titrations, after addition of titrants the sample was sonicated for $\sim 10 \mathrm{~s}$ and allowed to stand for $\sim 5 \mathrm{~min}$ before measurement. For kinetics measurements with $\mathrm{CH}_{3} \mathrm{SO}_{3} \mathrm{H}$ or $\mathrm{Zn}(\mathrm{OTf})_{2}$ as activators, all the reactants were mixed together in $\mathrm{CH}_{3} \mathrm{CN}$, and the absorbance at $255 \mathrm{~nm}$ or $269 \mathrm{~nm}$ was recorded. For kinetics measurements with $\operatorname{In}(\mathrm{OTf})_{3}$, the host 1 and 2-propanol was mixed together in $\mathrm{CH}_{3} \mathrm{CN}$, and the absorbance spectra was recorded. The solution of $\operatorname{In}(\mathrm{OTf})_{3}$ was then added quickly and time was recorded. The absorbance at $255 \mathrm{~nm}$ was followed immediately, and the starting time was also recorded. All the concentrations are listed in the captions of corresponding figures.

Table S1. Chemical shift changes (ppm) of host 2 upon binding of Brønsted and Lewis acids in $\mathrm{CD}_{3} \mathrm{CN}$.

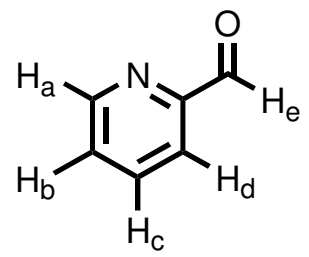

\begin{tabular}{cccccccc}
\hline Entry & Acid & $\mathrm{H}_{\mathrm{a}}$ & $\mathrm{H}_{\mathrm{b}}$ & $\mathrm{H}_{\mathrm{c}}$ & $\mathrm{H}_{\mathrm{d}}$ & $\mathrm{H}_{\mathrm{e}}$ & Carbonyl C \\
\hline 1 & no acid & 8.80 & 7.62 & 7.97 & 7.94 & 10.02 & 195.1 \\
\hline 2 & $\mathrm{CH}_{3} \mathrm{SO}_{3} \mathrm{H}(5$ equiv) & 8.98 & 8.31 & 8.86 & 8.56 & 10.10 & 185.8 \\
\hline 3 & $\mathrm{In}(\mathrm{OTf})_{3}(1$ equiv) & 8.95 & 8.32 & 8.88 & 8.58 & 10.08 & 185.7 \\
\hline 4 & $\mathrm{Zn}(\mathrm{OTf})_{2}(1$ equiv) & 8.92 & 8.12 & 8.50 & 8.44 & 10.01 & 195.5 \\
\hline
\end{tabular}


Table S2. Chemical shift changes (ppm) of host 1 upon binding of Lewis acid in $\mathrm{CD}_{3} \mathrm{CN}$.<smiles>Cc1nc(C(=O)C(C)(F)F)c(C)c(C)c1C</smiles>

\begin{tabular}{cccccccc}
\hline Entry & Acid & $\mathrm{H}_{\mathrm{a}}$ & $\mathrm{H}_{\mathrm{b}}$ & $\mathrm{H}_{\mathrm{c}}$ & $\mathrm{H}_{\mathrm{d}}$ & $\mathrm{H}_{\mathrm{e}}$ & $\mathrm{F}$ \\
\hline 1 & no acid & 8.77 & 7.69 & 8.03 & 8.12 & 7.19 & -131.4 \\
\hline 2 & $\mathrm{Zn}(\mathrm{OTf})_{2}(1$ equiv) & 8.86 & 7.90 & 8.24 & 8.30 & 7.15 & -130.1 \\
\hline 3 & $\mathrm{CH}_{3} \mathrm{SO}_{3} \mathrm{H}$ (5 equiv) & 8.97 & 8.09 & 8.51 & 8.41 & 7.01 & -129.7 \\
\hline $4^{\mathrm{a}}$ & $\mathrm{In}(\mathrm{OTf})_{3}(1$ equiv) & $/$ & $/$ & $/$ & $/$ & 6.97 & $/$ \\
\hline
\end{tabular}

a. The indium complex is so reactive that hydrate is the major component. All aromatic signals overlap with others.

Scheme S1. Addition of 2-propanol to hosts 1 and control 4 (30- $40 \mathrm{mM})$ in the presence of varied amount of indium triflate in $\mathrm{CD}_{3} \mathrm{CN}$.
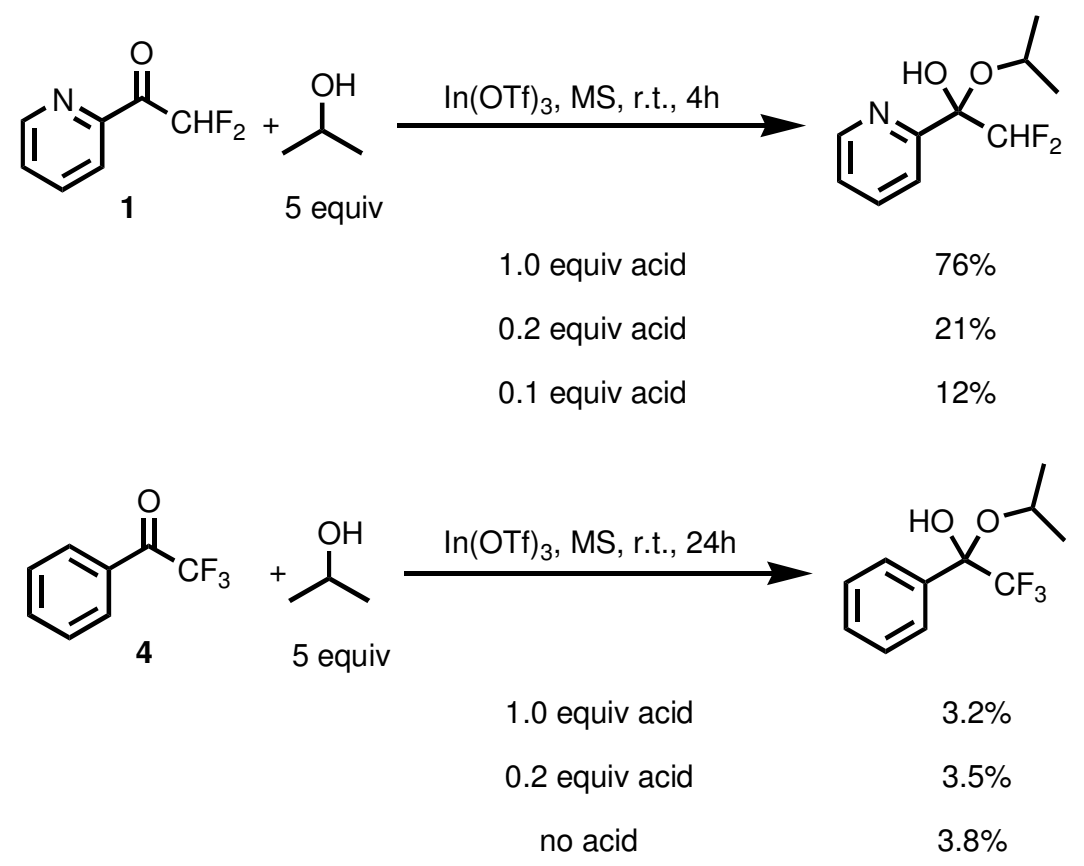
Scheme S2. Addition of 2-propanol to host $1(\sim 36 \mathrm{mM})$ in the presence of varied amount of methanesulfonic acid in $\mathrm{CD}_{3} \mathrm{CN}$.

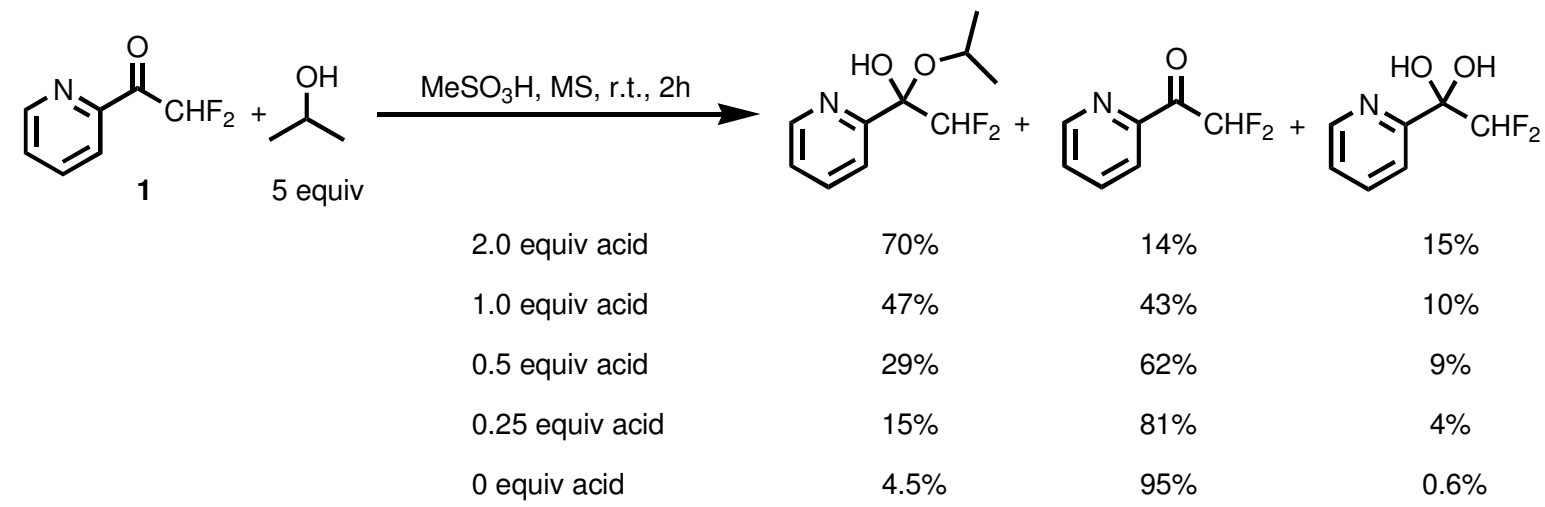

Scheme S3. Addition of 2-propanol to host $2(\sim 190 \mathrm{mM})$ in the presence of methanesulfonic acid.

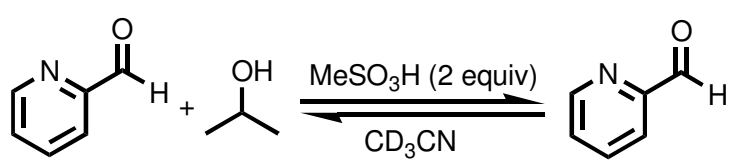

1 eq. $\quad 1$ eq. $\quad 2 \mathrm{~h}$

1 eq. $\quad 1$ eq. $\quad 6 \mathrm{~h}$

1 eq. $\quad 1$ eq. $\quad 20 \mathrm{~h}$

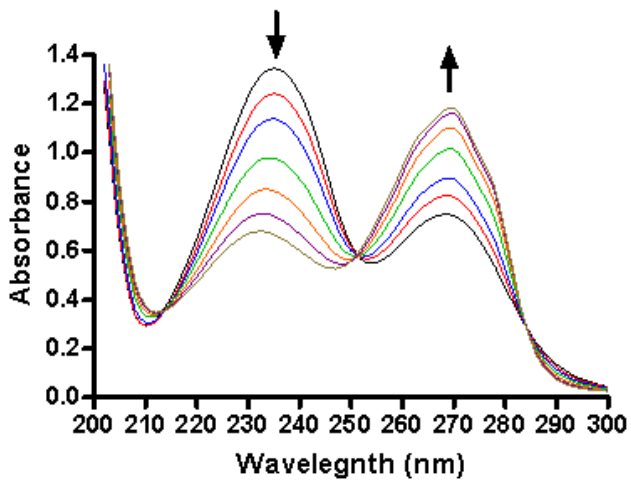<smiles>CC(C)OC(O)c1ccccn1</smiles>

$62 \%$

$57 \%$

$51 \%$<smiles>OCc1ccccn1</smiles>

$6 \%$

$8 \%$

$9 \%$<smiles>CC(C)OC(OC(C)C)c1ccccn1</smiles>

$5 \%$

$10 \%$

$17 \%$

Figure S1. Titration of $\mathrm{MeSO}_{3} \mathrm{H}$ into host $(0.17 \mathrm{mM})$ solution in $\mathrm{CH}_{3} \mathrm{CN}$. This is an acid-base reaction and the equilibrium is readily established. 

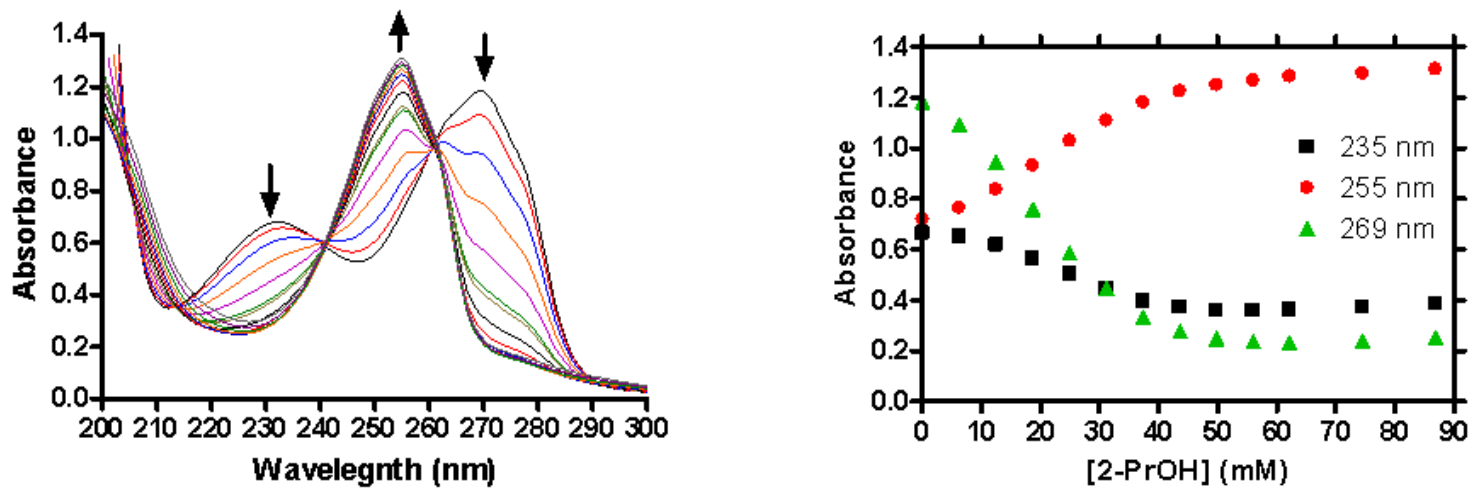

Figure S2. Titration of 2-propanol into the solution of $\mathbf{1}(0.17 \mathrm{mM})$ and $\mathrm{CH}_{3} \mathrm{SO}_{3} \mathrm{H}$ (9.16 mM) in $\mathrm{CH}_{3} \mathrm{CN}$ (left panel) and its binding isotherm (right panel).
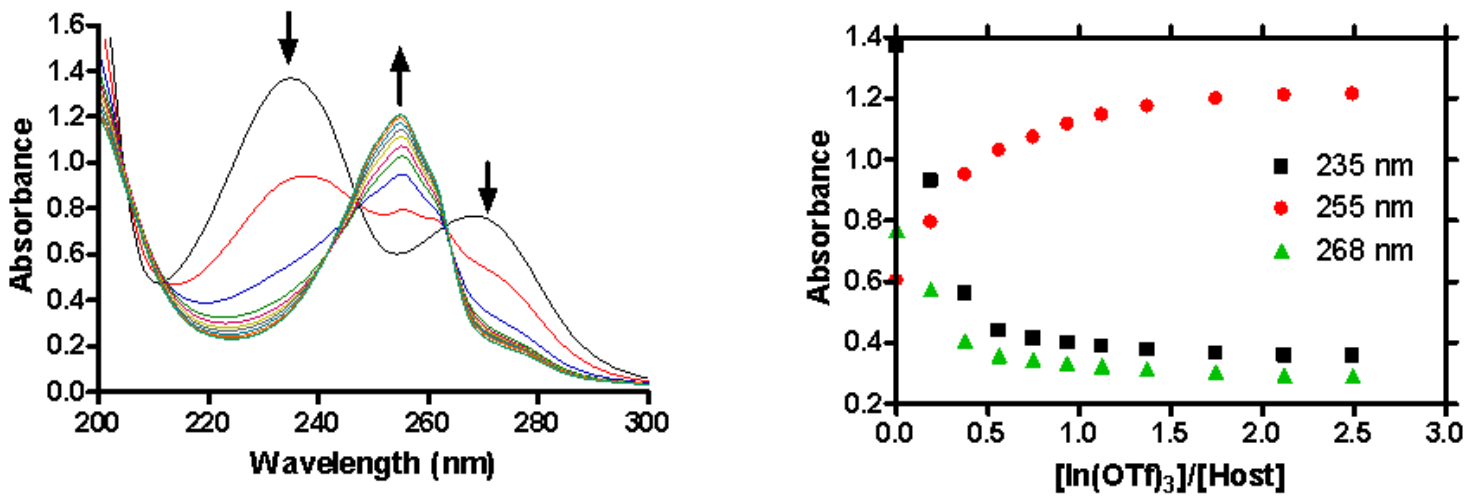

Figure S3. Titration of $\operatorname{In}(\mathrm{OTf})_{3}$ into host $(0.17 \mathrm{mM})$ solution in $\mathrm{CH}_{3} \mathrm{CN}$. The complex of host with indium is so reactive that it will form hydrate immediately. 

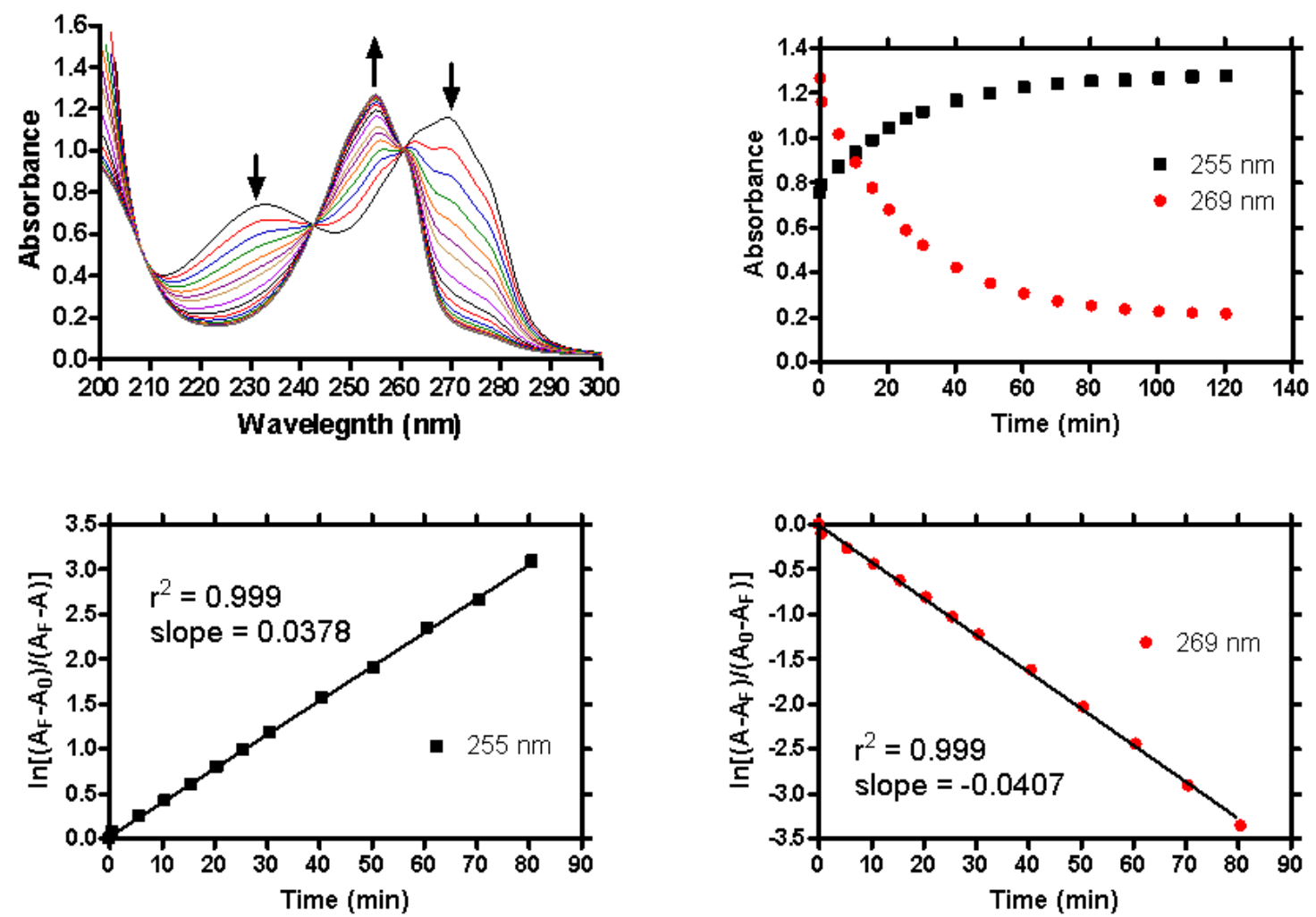

Figure S4. (Top panel) Time dependence of absorbance spectra of host $1(0.17 \mathrm{mM})$, 2-propanol $(19.25 \mathrm{mM})$ and $\mathrm{CH}_{3} \mathrm{SO}_{3} \mathrm{H}(9.40 \mathrm{mM})$ in $\mathrm{CH}_{3} \mathrm{CN}$ and data points at two wavelengths. (Bottom panel) Linear fitting of data points at $255 \mathrm{~nm}$ and $269 \mathrm{~nm}$. 

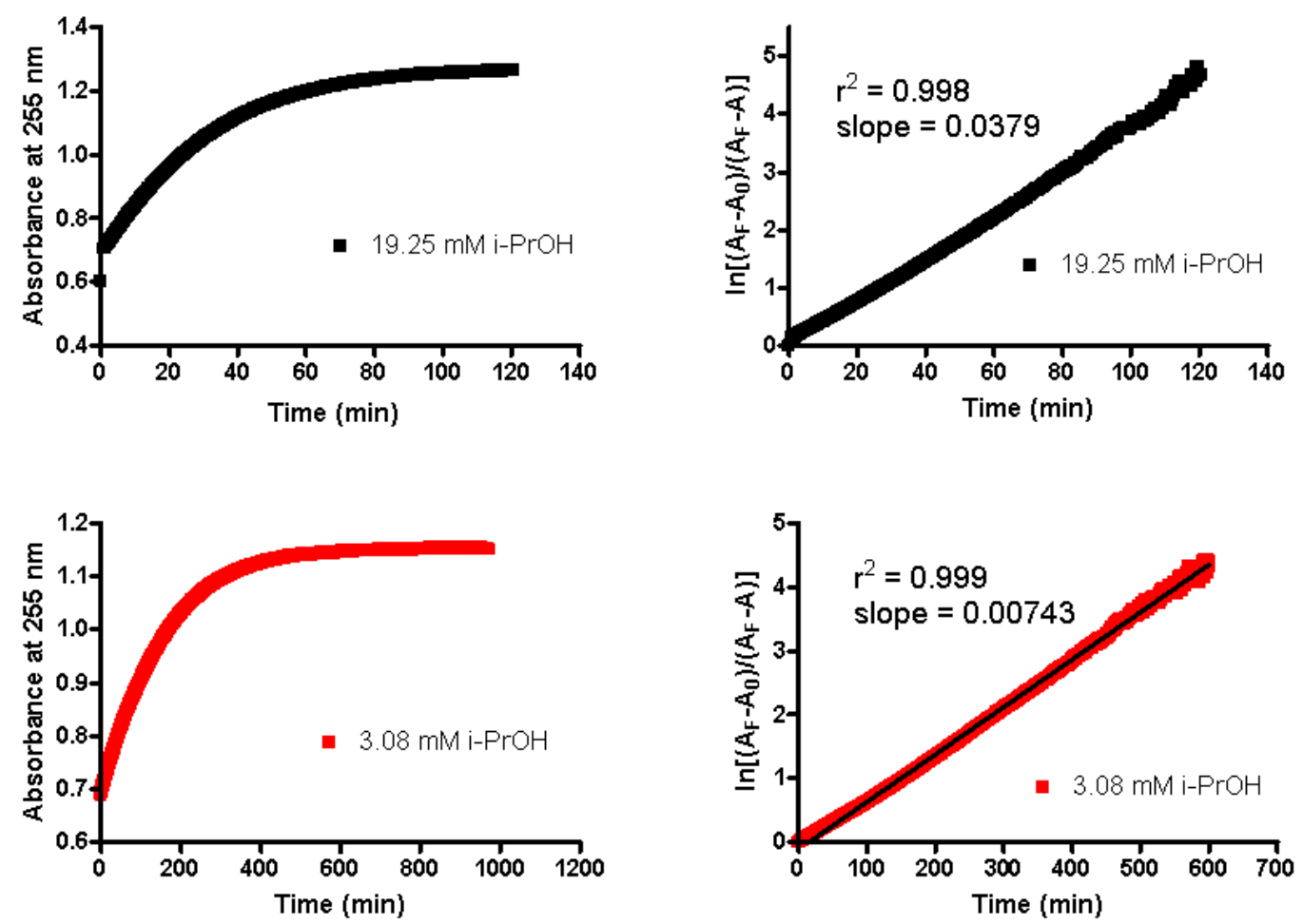

Figure S5. Monitoring of the peak at $255 \mathrm{~nm}$ in the presence of host $1(0.17 \mathrm{mM})$, $\mathrm{MeSO}_{3} \mathrm{H}$ (9.41 mM) and 2-propanol (top panel: $19.25 \mathrm{mM}$; bottom panel: $3.08 \mathrm{mM}$ ) and data fitting. 


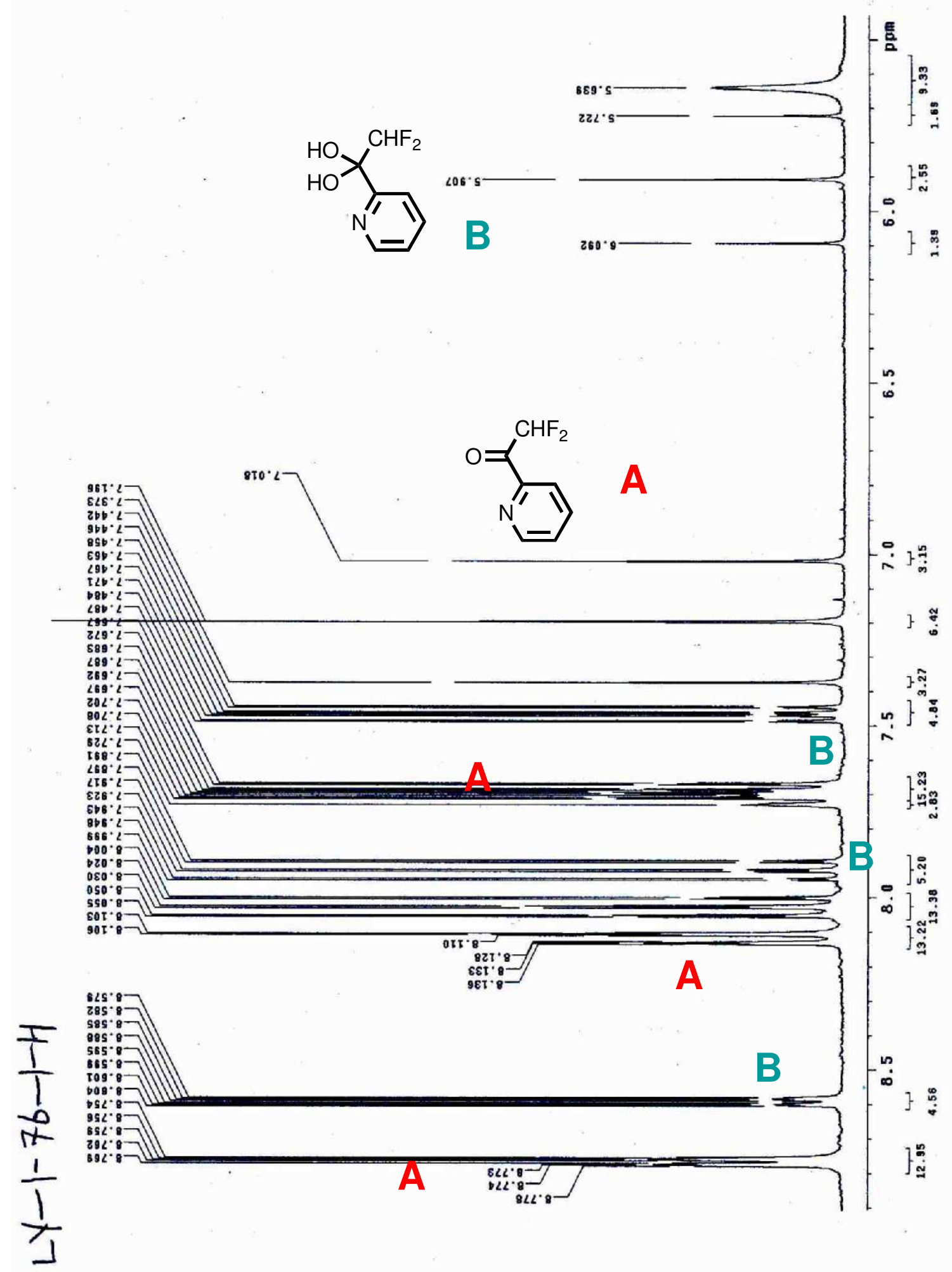

Figure S6. ${ }^{1} \mathrm{H}-\mathrm{NMR}$ of $\mathbf{1}$ with its hydrate in $\mathrm{CD}_{3} \mathrm{CN}$. 


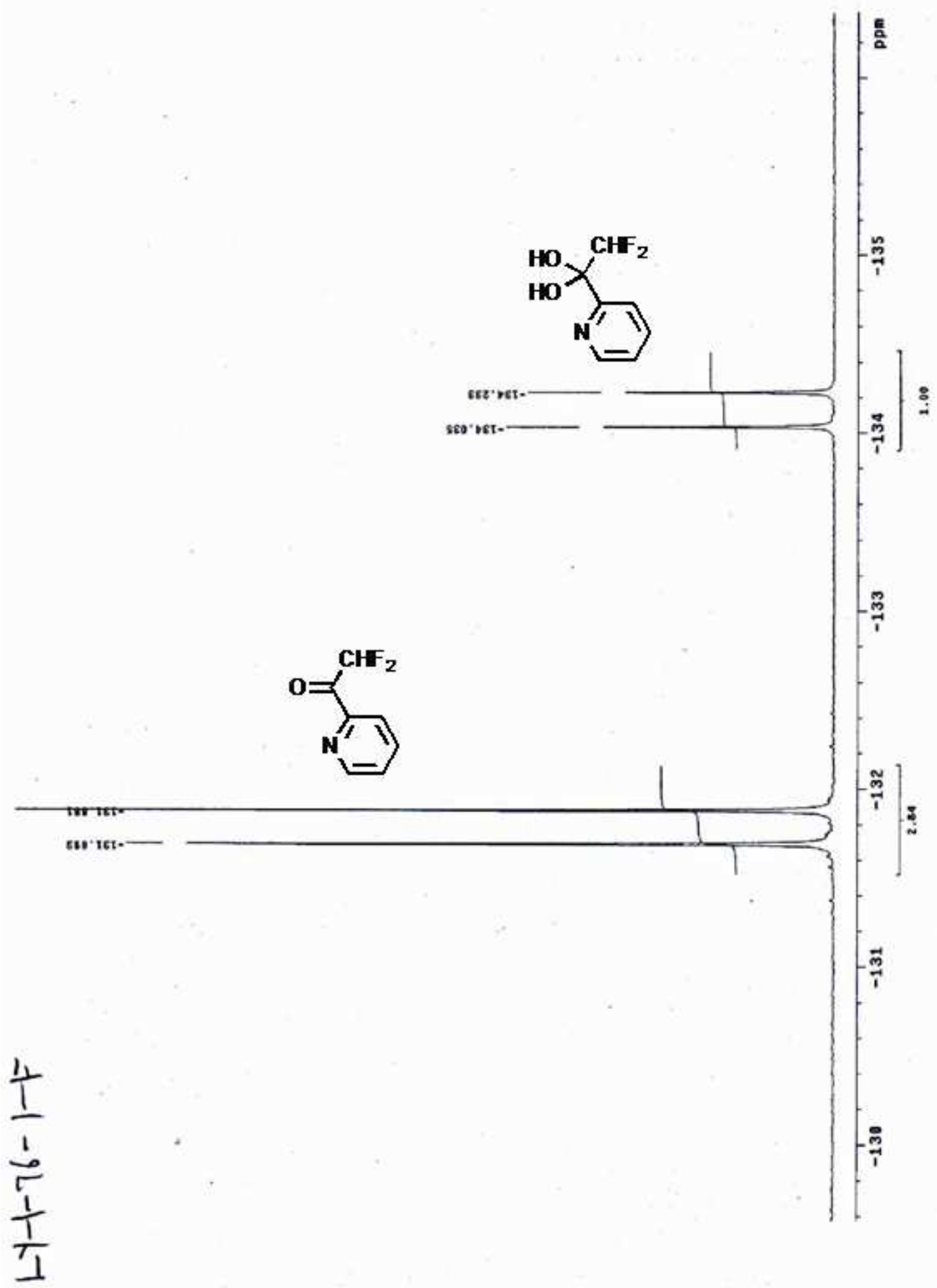

Figure S7. ${ }^{19} \mathrm{~F}-\mathrm{NMR}$ of $\mathbf{1}$ with its hydrate in $\mathrm{CD}_{3} \mathrm{CN}$. 


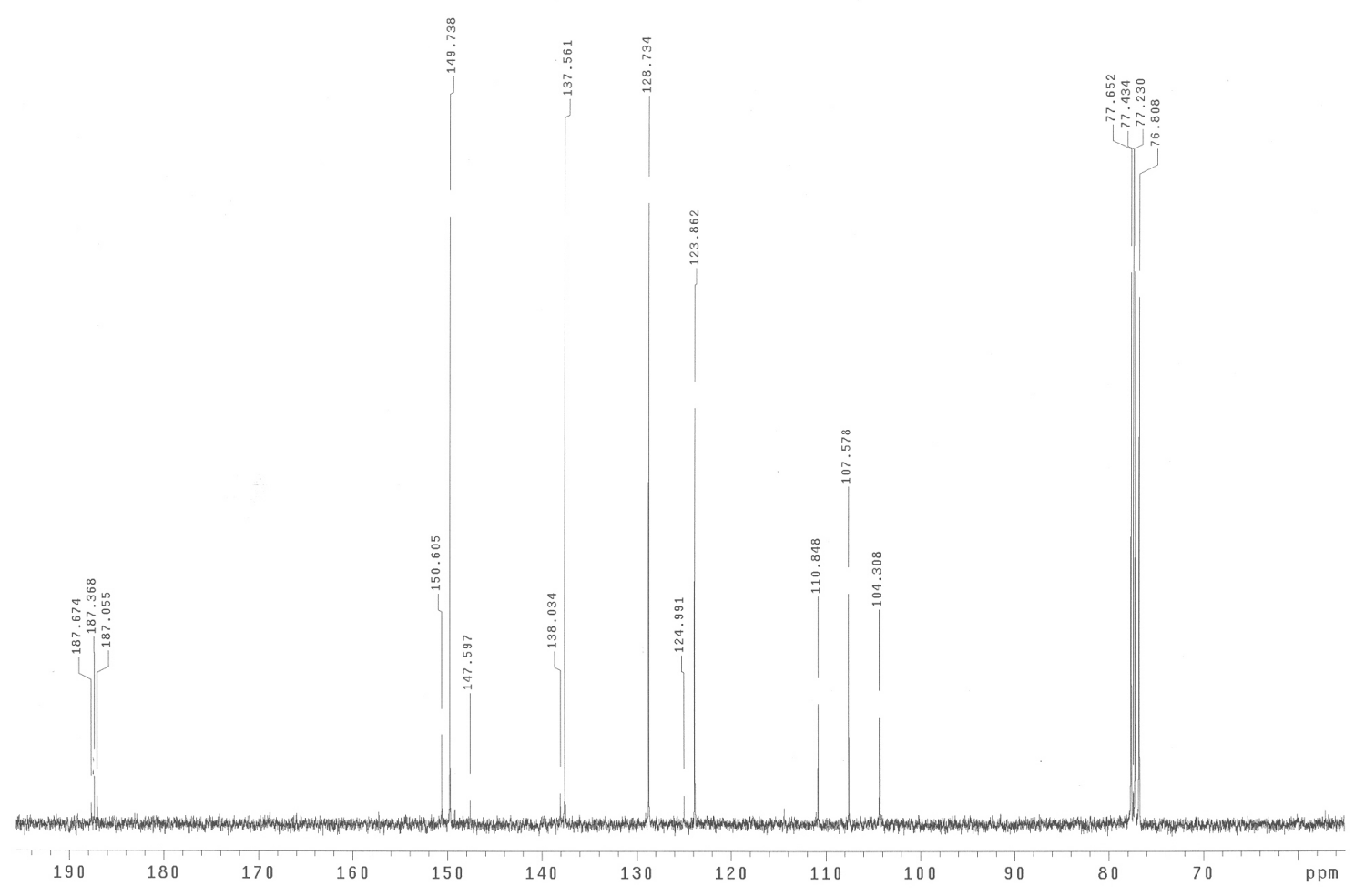

Figure S8. ${ }^{13} \mathrm{C}-\mathrm{NMR}$ of $\mathbf{1}$ with its hydrate in $\mathrm{CDCl}_{3}$. 
LY-1-89-1-CD3CN

Archive directory:
Sample di dectory:

Pulse Sequence: s2pur

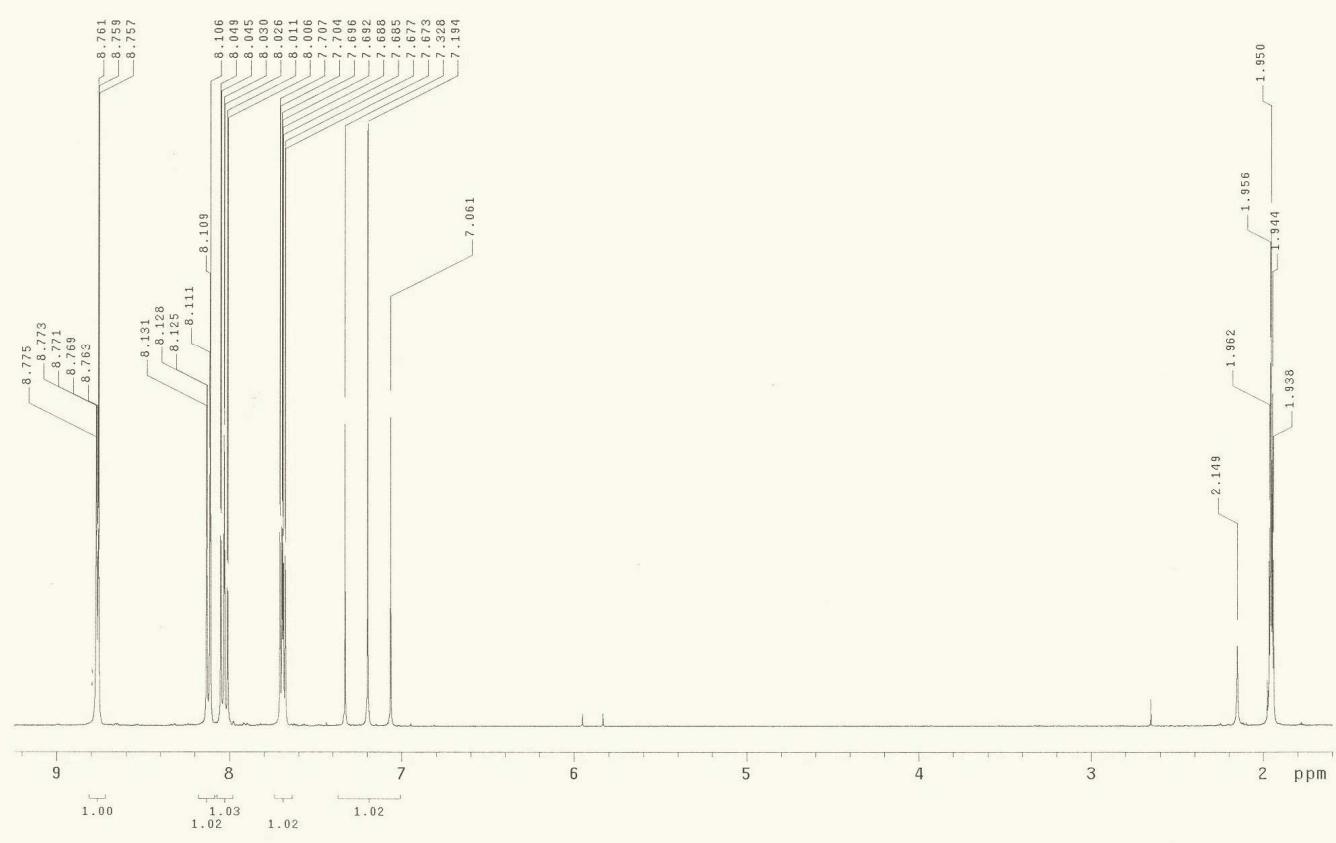

Figure S9. ${ }^{1} \mathrm{H}-\mathrm{NMR}$ of 1 after dehydration in $\mathrm{CD}_{3} \mathrm{CN}$. 
LY-1-89-1-CD3CN

Archive directory:
Sample directory:

Pulse Sequence: s2pul

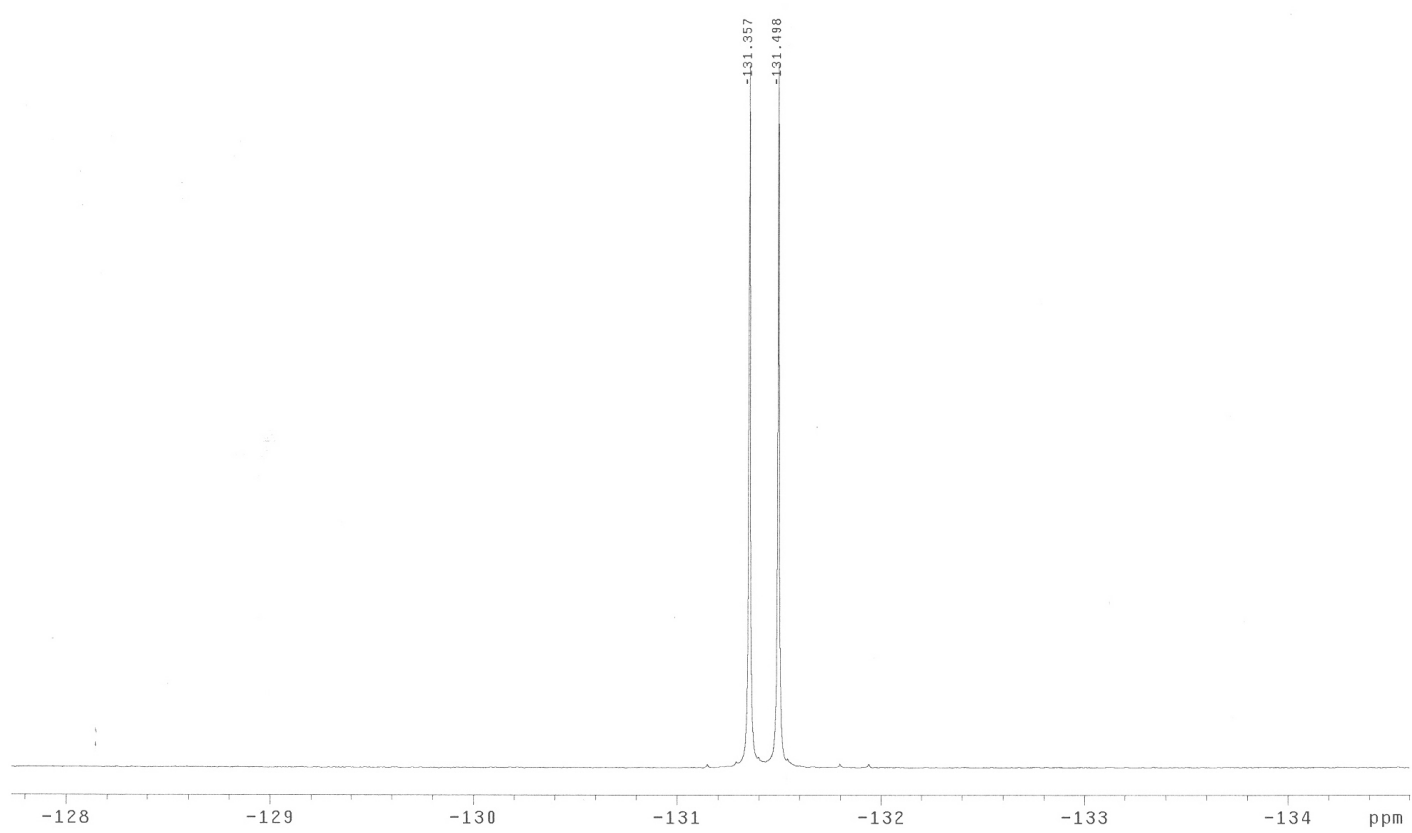

Figure S10. ${ }^{19} \mathrm{~F}-\mathrm{NMR}$ of 1 after dehydration in $\mathrm{CD}_{3} \mathrm{CN}$. 


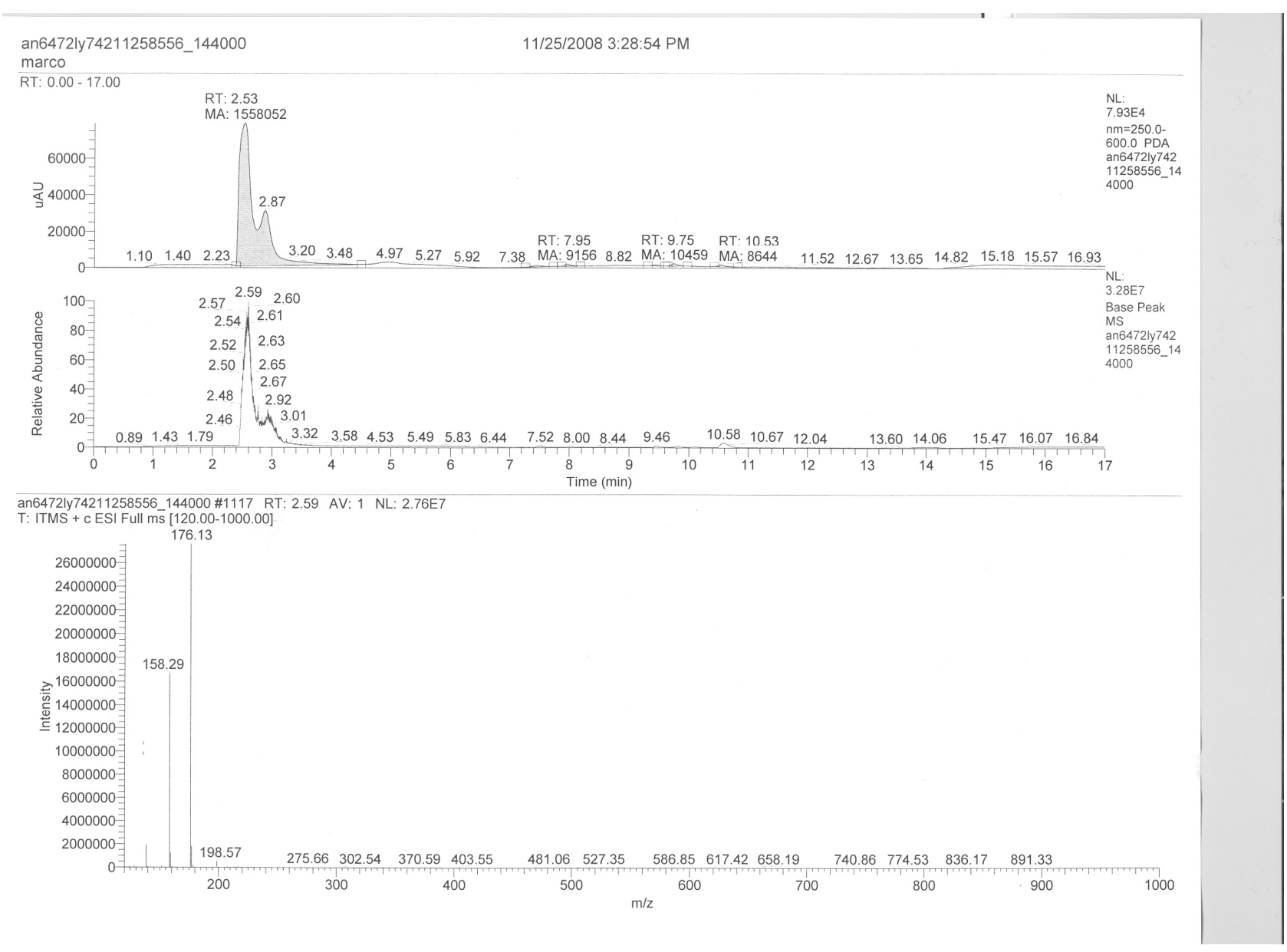

Figure S11. LC/MS data of 1. 


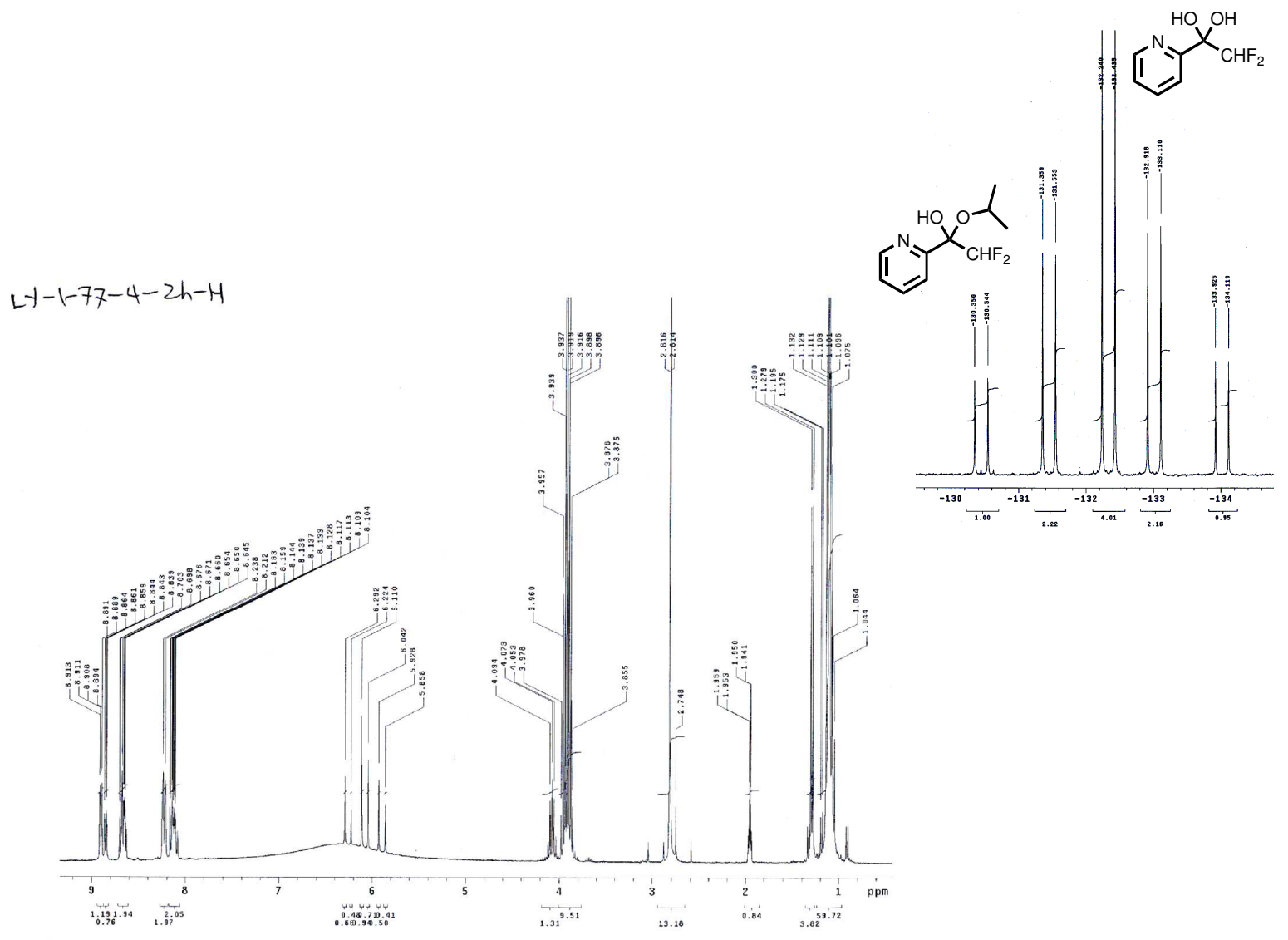

Figure S12. ${ }^{1} \mathrm{H}-\mathrm{NMR}$ and ${ }^{19} \mathrm{~F}-\mathrm{NMR}$ of the reaction of 1 with 2 -propanol (5 equiv) in the presence of methanesulfonic acid (2 equiv) in $\mathrm{CD}_{3} \mathrm{CN}$. Both hemiacetal and hydrate were observed. 


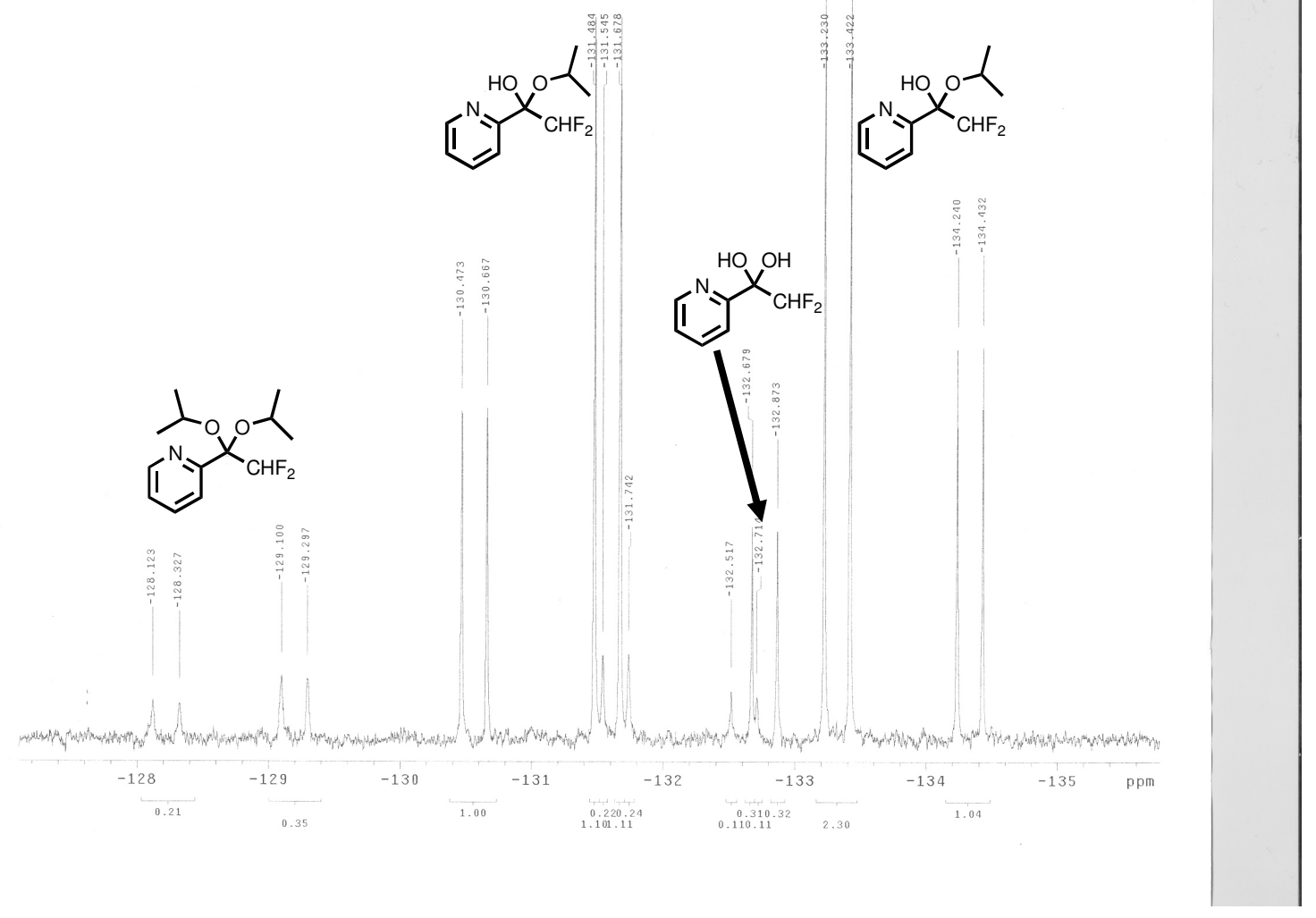

Figure S13. ${ }^{19} \mathrm{~F}-\mathrm{NMR}$ of the reaction of 1 with 2-propanol (5 equiv) in the presence of $\operatorname{In}(\mathrm{OTf})_{3}$ (1 equiv) and $3 \AA$ MS in $\mathrm{CD}_{3} \mathrm{CN}$. 


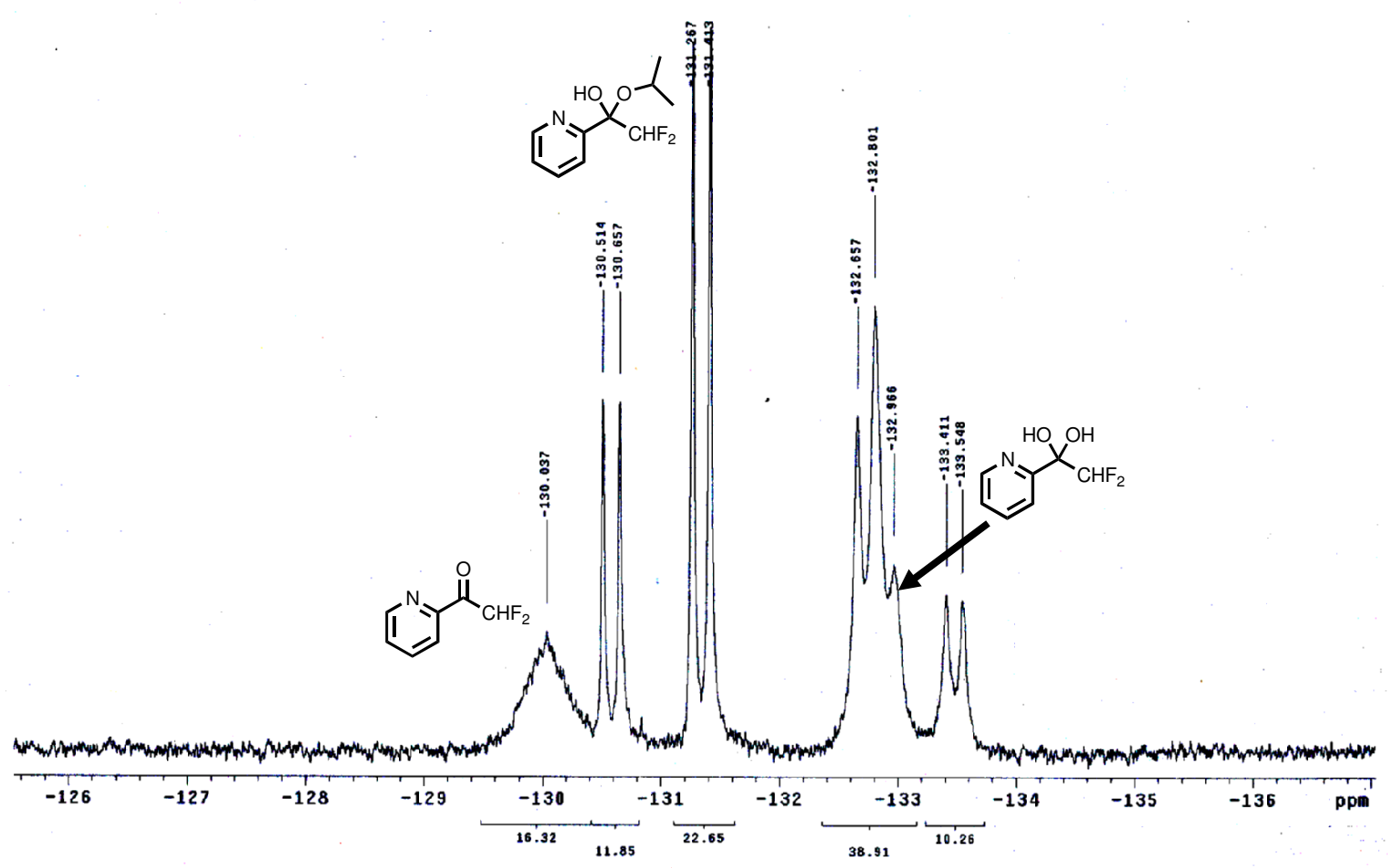

Figure S14. ${ }^{19} \mathrm{~F}-\mathrm{NMR}$ of the reaction of 1 with 2-propanol (5 equiv) in the presence of $\mathrm{Zn}(\mathrm{OTf})_{2}$ (1 equiv) in $\mathrm{CD}_{3} \mathrm{CN}$. 


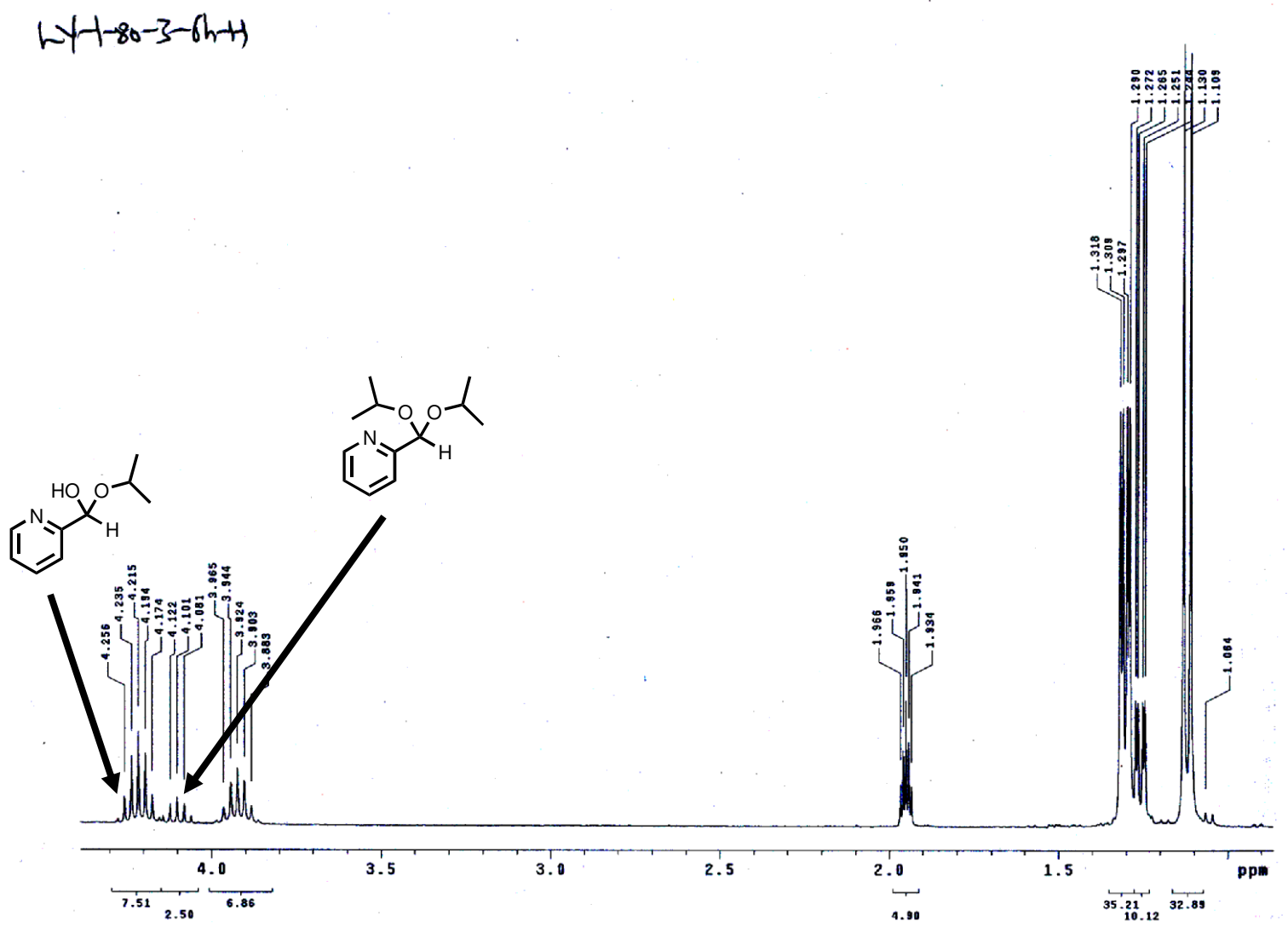

Figure S15. Region of ${ }^{1} \mathrm{H}-\mathrm{NMR}$ of the reaction of 2 with 2-propanol (1 equiv) in the presence of $\operatorname{In}(\mathrm{OTf})_{3}\left(0.5\right.$ equiv) in $\mathrm{CD}_{3} \mathrm{CN}$ after $6 \mathrm{~h}$. 